\title{
Comparative Analysis of PPPOE and SSTP Performance in Microtic (Analisis Perbandingan Kinerja PPPOE dan SSTP Pada Mikrotik)
}

\author{
Andika Agus Slameto ${ }^{1}$, Rahmat Hidayat ${ }^{2}$ \\ 1,2Universitas Amikom Yogyakarta, Indonesia \\ Email: rmkt.andika@amikom.ac.id
}

\begin{abstract}
Tunneling is the process of packaging data sent by other protocols in a network. Point to point over Ethernet (PPPOE) and Secure Socket Tunneling Protocol (SSTP) are protocols that function or are designed to carry out tunneling processes. Data security in this case is a top priority, with the encapsulation and authentication process making tunnels one of the many ways to secure data in a network. Besides security, network performance is something that must be considered in providing good services. In the process of testing the performance of PPPOE and SSTP using the Quality of Service method, it can be concluded that SSTP is better in the parameters of Througput, Delay, and Jitter while PPPOE is better in Packet Loss. In the security testing phase, both protocols have encapsulated data packets sent over an http-based web.
\end{abstract}

Keywords: Tunnel, PPPOE, SSTP, QOS, Security, Network

\begin{abstract}
Abstrak
Tunneling merupakan proses pengemasan data yang dikirim oleh protokol lain dalam suatu jaringan. Point to point over Ethernet (PPPOE) dan Secure Socket Tunneling Protocol (SSTP) adalah protokol yang berfungsi atau dirancang untuk melakukan proses tunneling. Keamanan data dalam hal ini adalah prioritas utama, dengan proses enkapsulasi dan otentikasi membuat terowongan salah satu dari banyak cara mengamankan data dalam jaringan. Selain keamanan, kinerja jaringan adalah sesuatu yang harus diperhatikan dalam memberikan layanan yang baik. Dalam proses pengujian kinerja PPPOE dan SSTP dengan metode Quality of Service, dapat disimpulkan bahwa SSTP lebih baik dalam parameter Througput, Delay, dan Jitter sedangkan PPPOE lebih baik dalam Packet Loss. Pada fase pengujian keamanan, kedua protokol telah melakukan enkapsulasi paket data yang dikirim melalui web yang berbasis http.
\end{abstract}

Kata kunci: Tunnel, PPPOE, SSTP, QOS, Security, Network

\section{Pendahuluan}

Keamanan dengan teknologi firewall tidak cukup menjamin sebuah keamanan data. Fitur tunnnel memberikan kemanan lebih dalam sebuah jaringan. Dengan di tambahkan proses encapsulation dan proses authentifikasi membuat keamanan sebuah jaringan semakin baik. Protocol tunnel memiliki banyak variasi, diantanya ialah PPTP, PPPOE, L2TP, IPSEC, SSTP dan juga OpenVPN. Dari beberapa protocol yang ada di pilih dua protocol yaitu PPPOE dan SSTP untuk dilakukan perbandingan terhadap kemanan dan kinerja yang berikan.

Selain memperhatikan masalah faktor kegagalan sistem, keamanan, skalabilitas, sebuh jaringan tentunya juga harus memperthatikan kualitas atau jaminan terhadap layanan yang diberikan kepada pelanggan. Untuk melakukan penilaian terhadap kinerja yag diberikan. Diterapkanlah metode analisis menggunakan quality of service, dimana terdapat beberapa paramter pengujian seperti througputh, packet loss, delay dan jitter.

Rein Rachman Putra, Ridha Muldina Negara, ST., MT., Dr.Ir.Rendy Munadi, 2015, melakukan penelitian tentang analisa Qos VPN PPPOE pada jaringan backbone wirelwss MPLS. Penelitian ini dilakukan untuk menangani masalah penambahan protokol PPPOE pada jaringan yang berpengaruh terhadap kualitas jaringan karena adanya proses enkapsulasi yang terjadi, maka diperlukan ada nya pengukuran QoS pada jaringan untuk menenentukan dampak dari protokol ini pada jaringan. Hasil dari penelitian yang dilakukan, terdapat kenaikan nilai delay pada saat menggunakan protokol PPPoE menjadi sebesar 6ms tanpa menggunakan layanan dan $171,1 \mathrm{~ms}$ untuk layanan video streaming[1]].

Eri Prasetyo, Amir Hamzah, Edhy Sutanta, 2016, melakukan penelitian tentang analisa quality of service kinerja poin to point protocol over ethernet (PPPOE) dan point to point tunneling protocol (PPPTP). Penelitian ini dilakukan untuk menganalisa kinerja protocol PPPOE dan SSTP menggunakan Qos sebagai landasan dari kinerja protocol tersebut, hal ini juga akan menentukan jaminan Qos berhubungan dengan seberapa baik kualitas layanan tertentu dapat dinikmati oleh pemakai. Hasil penelitian menunjukkan bahwa PPPoE dan PPTP memiliki kualitas yang hampir sama baiknya,tetapi PPTP lebih baik dalam menangani jaringan yang menggunakan layanan VOIP 
yang erat hubungannya dengan jitter. PPTP juga lebih baik dalam menangani penggunaan bandwidth secara maksimal yang berhubungan dengan throughput[2].

Kaseger Arthur Farly, Xaverius B. N. Najoan, Arie S. M. Lumenta, 2017, melakukan penelitian tentang Perancangan dan Implementasi VPN Server dengan menggunakan Protokol SSTP (Secure Socket Tunneling Protocol) Studi Kasus Kampus Universitas Sam Ratulangi. Penelitian ini dilakukan untuk mengimplementasi keamanan jaringan menggunakan protokol SSTP dan L2TP. Selain melakukan keamanan, pada penelitian ini dilakukan juga perbandingan kinerja protocol yang digunakan. Hasil dari penelitian yang dilakukan berdasarkan percobaan attacking menggunakan software Pingflood, ternyata mempengaruhi kinerja Server yang mengakibatkan aktivitas Server menjadi lambat dan banyak terjadi Request Time Out saat melakukan percobaan tersebut[3].

I Putu Hariyadi, Raisul Azhar, 2017, Pengamanan Layanan Private Cloud Storage Menggunakan HTTPS, IPTables dan SSTP. Penelitian ini dilatar belakangi adanya permasalahan yang dihadapi meliputi tersebarnya data dari masing-masing bagian di setiap komputer staf atau kepala bagian yang menyebabkan pencarian data baik di dalam maupun antar bagian menjadi tidak efisien dan aktivitas backup untuk pengamanan data sulit dilakukan sehingga rentan terjadi kehilangan data sebagai akibat penyimpanan data yang tersebar. Ole sebab itu dibuat sebuah cloud Storage untuk penyimpanan terpusat. Sedangkan untuk keamanan menerapkan Secure Socket Tunneling Protocol (SSTP) pada Router Gateway yang dapat menjembatani kebutuhan akses bagi civitas akademika yang sedang berada diluar kampus ke layanan Private Cloud Storage dari Internet melalui Remote AccessVirtual Private Network (VPN)sekaligus pengamanan komunikasinya.SSTP merupakan bentuk baru dari VPN tunnel yang menyediakan mekanisme untuk mengenkapsulasi trafik Point-to-Point Protocol (PPP) melalui jalur Secure Socket Layer (SSL) dari protokol HTTPS[4].

Sugiyatno, Prima Dina Atika, 2018, melakukan penelitian tentang Virtual Private Network (VPN) Secure Socket Tunneling Protocol (SSTP) Menggunakan Raspberry Pi. Penelitian ini dirancang suatu koneksi VPN SSTP dengan server Raspberry Pi dan client PC dengan sistem operasi Ubuntu. Dan juga, dibuat suatu rancangan VPN PPTP sebagai perbandingan terhadap VPN SSTP. Kemudian dilakukan pengujian terhadap performa dan keamanannya. Pada pengujian performa, parameter yang diuji adalah packet loss, round trip time dan SFTP file transfer. Dan pada pengujian keamanan, parameter yang diuji adalah sniffing. Hasil dari penelitian ini menunjukkan bahwa VPN SSTP sedikit lebih baik daripada VPN PPTP, terutama pada pengujian packet loss dan round trip time. Tetapi pada pengujian SFTP file transfer, VPN PPTP lebih baik daripada VPN SSTP. Sedangkan hasil dari pengujian keamanan, menunjukkan bahwa VPN SSTP aman terhadap serangan sniffing, hal itu ditunjukkan pada hasil yang didapat dimana username dan password yang digunakan untuk login tidak dapat diketahui oleh attacker, sedangkan pada VPN PPTP username-nya dapat diketahui, tetapi password tidak dapat terbaca karena terenkripsi MSCHAPv2[5].

Berdasarkan latar belakang diatas dan beberapa referensi maka dalam penelitian ini akan dilakukan pengujian dengan metode quality of service terhadap kinerja dari protokol PPPOE dan SSTP, dilakukan pengujian dengan menggunakan streaming youtube dan download file melalui intenet download manager. Pengujian dilakukan dengan batas waktu hingga 5 menit dalam satu kali uji coba. Hasil dari pengujian akan dilakukan analisis untuk menentukan perbandingan dari kedua kinerja protocol yang ada manakah yang lebih baik

\section{Metode Penelitian}

Metode yang digunakan dalam penelitian ini dilakukan menggunakan metode eksperimen. Dimana langkahlangkahnya adalah sebagai berikut:

a. Proses identifikasi masalah.

Pada langkah ini dilakukan pengujian awal terhadap kinerja secara umum Protokol PPPOE dan SSTP dari segi kualitas bandwith untuk proses upload dan download. Pengujian ini dilakukan sebanyak 3 kali dan menggunakan bandwith sebesar $5 \mathrm{Mb}$.

1. Pengujian PPPOE

Pada pengujian pertama terdapat kecepetan download sebesar 4.88 Mbps dan upload sebesar 4.47 Mbps, pada pengujian kedua terdapat download sebesar 4.90 Mbps dan upload sebesar 4.83 Mbps, dan pada pengujian ketiga download sebesar 4.89 Mbps dan upload sebesar 4.45 Mbps. Dari hasil 
pengujian diatas diambil sebuah kesimpulan dimana kecepatan download pada PPPOE lebih besar daripada kecepatan upload.

2. Pengujian SSTP

Pada pengujian pertama terdapat kecepetan download sebesar 4.93 Mbps dan upload sebesar 6.87 Mbps, pada pengujian kedua terdapat download sebesar 4.54 Mbps dan upload sebesar 5.15 Mbps, dan pada pengujian ketiga download sebesar 4.23 Mbps dan upload sebesar 5.50 Mbps. Dari hasil pengujian diatas diambil sebuah kesimpulan dimana kecepatan upload pada SSTP lebih besar daripada kecepatan download.

b. Alat dan bahan yang digunakan

Pada penelitian ini alat dan bahan yang digunakan adalah sebagai berikut :

1. Mikrotik RB941-2nD-TC

2. Aplikasi Wereshark

3. Aplikasi Winbox

4. Aplikasi Speedtest

5. Aplikasi Microsoft Excel

c. Perancangan Topologi

1. Perancangan Topologi PPPOE

Untuk rancangan topologi beserta rancangan alamat IP yang digunakan untuk PPPOE dapat dilihat pada gambar 1 dan tabel 1 berikut.

\section{TOPOLOGI PPPOE}

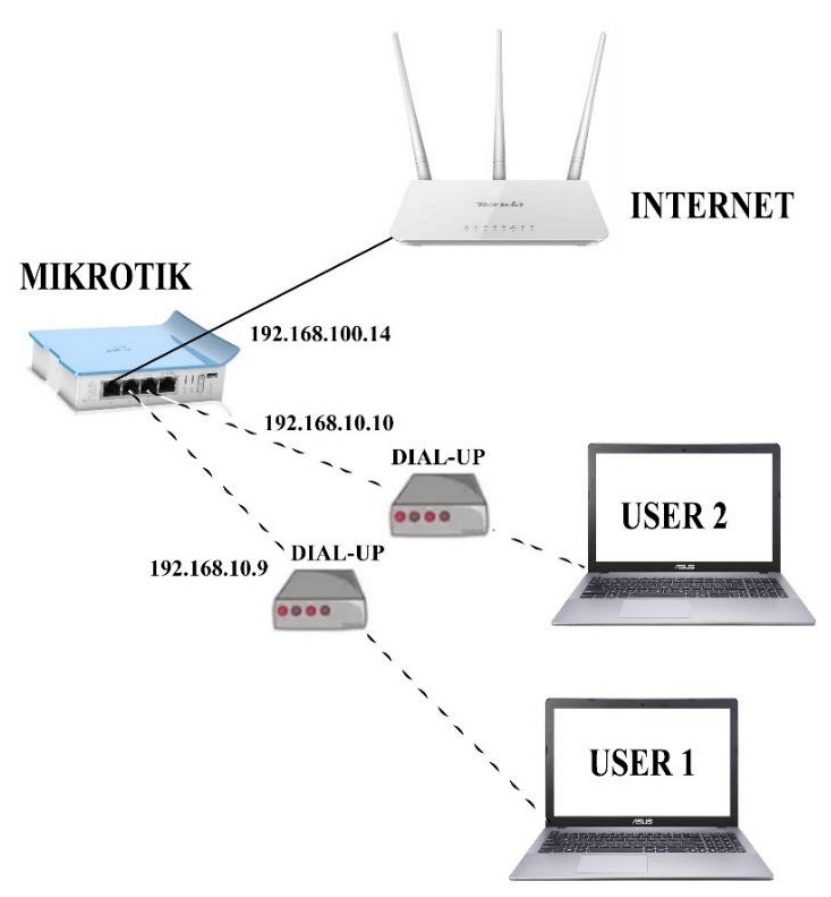

Gambar 1. Topologi PPPOE 
Tabel 1. Rancangan alamat IP untuk topologi PPPOE

\begin{tabular}{llll}
\hline No & $\begin{array}{c}\text { Nama } \\
\text { Perangkat } \\
\text { Device }\end{array}$ & \multicolumn{1}{c}{ Interface } & IP Address \\
\hline 1. & $\begin{array}{l}\text { Switch } \\
\text { Tenda } \\
\text { (Internet) }\end{array}$ & Eth 2 & $192.168 .100 .1 / 24$ \\
& Mikrotik & Eth 1 & \\
\hline 2. & & Wlan PPPOE & $192.168 .100 .14 / 24$ \\
& & Wlan/Dial-up & $192.168 .20 .10 / 24$ \\
& & PPPOE & \\
\hline 3. & User 1 & Wlan/Dial-up & $192.168 .20 .9 / 24$ \\
& & PPPOE & \\
\hline 4. & User 2 & & \\
& & & \\
\hline
\end{tabular}

2. Perancangan Topologi SSTP

Untuk rancangan topologi beserta rancangan alamat IP yang digunakan untuk SSTP dapat dilihat pada gambar 2 dan tabel 2 berikut.

\section{TOPOLOGI SSTP}

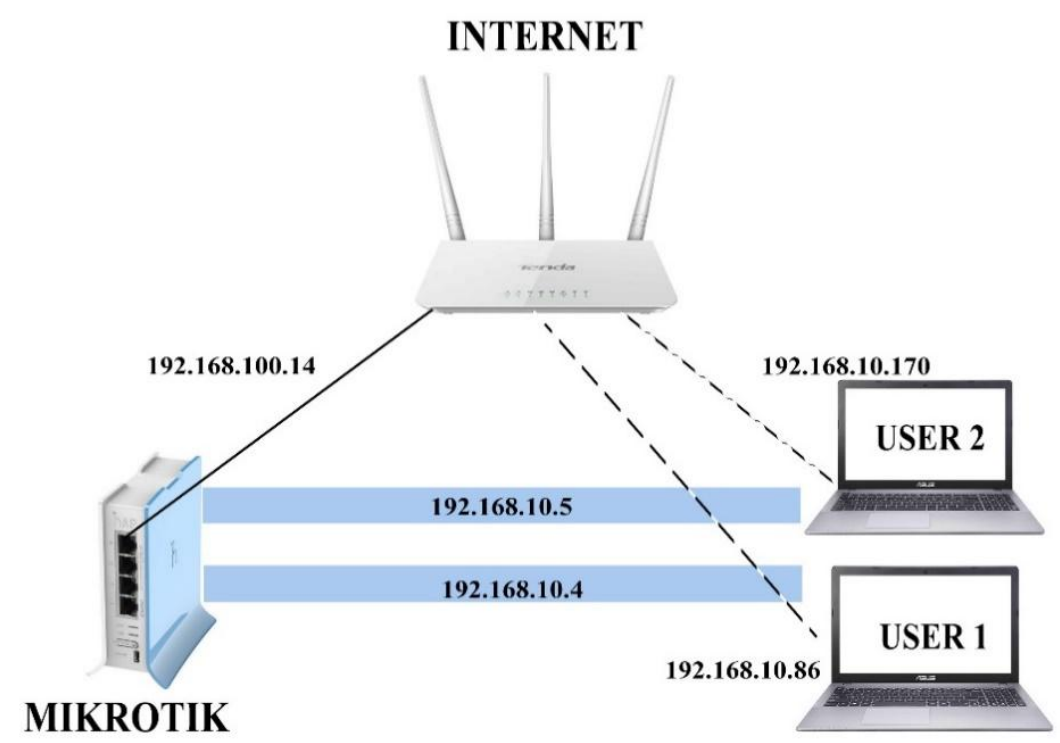

Gambar 2. Rancangan Topologi SSTP 
Tabel 2. Rancangan alamat IP untuk topologi SSTP

\begin{tabular}{|c|c|c|c|}
\hline No & $\begin{array}{c}\text { Nama } \\
\text { Perangkat / } \\
\text { Device }\end{array}$ & Interface & IP Address \\
\hline 1. & $\begin{array}{l}\text { Switch } \\
\text { Tenda } \\
\text { (Internet) }\end{array}$ & Eth 2 & $192.168 .100 .1 / 24$ \\
\hline \multirow[t]{2}{*}{2.} & Mikrotik & Eth 1 & $192.168 .100 .14 / 24$ \\
\hline & & Wlan SSTP & $192.168 .10 .1 / 24$ \\
\hline \multirow[t]{2}{*}{3.} & User 1 & Wlan & $192.168 .100 .86 / 24$ \\
\hline & & Tunnel SSTP & 192.168 .10 .5 \\
\hline \multirow[t]{2}{*}{4.} & User 2 & Wlan & $192.168 .100 .170 / 24$ \\
\hline & & Tunnel SSTP & 192.168 .10 .4 \\
\hline
\end{tabular}

3. Perancangan uji

Pengujian yang dilakukan pada penelitan ini adalah menggunakan parameter Quality Of Service dengan yang terdiri dari pengujian Throughput, Packet Loss, Delay dan Jitter. [6]

1. Pengujian Throughput

Pengujian ini dilakukan untuk mengetahui jumlah total kedatangan paket yang sukses yang diamati pada tujuan selama interval waktu tertentu dibagi oleh durasi interval waktu tersebut [6] .

Untuk indeks kualitas throughput dapat dilihat pada tabel 3 dibawah ini.

Tabel 3. Indeks kualitas Throughput []]

\begin{tabular}{lcc}
\hline $\begin{array}{c}\text { Kategori } \\
\text { Throughput }\end{array}$ & $\begin{array}{c}\text { Throughput } \\
\text { (bps) }\end{array}$ & Indeks \\
\hline Sangat Bagus & $100 \%$ & 4 \\
\hline Bagus & $75 \%$ & 3 \\
\hline Sedang & $50 \%$ & 2 \\
\hline Cukup & $<25 \%$ & 1 \\
\hline
\end{tabular}

Untuk pengukuran hasil dari throughput menggunakan persaan dibawah ini [ㅁ] . 


$$
\text { Throughput }=\frac{\text { Paket data diterima }}{\text { Lama pengamatan }}
$$

2. Pengujian Packet Loss

Pengujian ini dilakukan untuk mengetahui jumlah total paket yang hilang. [ㅁ]

Untuk indeks kualitas Packet Loss dapat dilihat pada tabel 4 dibawah ini.

Tabel 4. Indeks kualitas Packet Loss [] $]$

\begin{tabular}{lcc}
\hline $\begin{array}{c}\text { Kategori } \\
\text { Packet Loss }\end{array}$ & Packet Loss & Indeks \\
\hline Sangat Bagus & $0 \%$ & 4 \\
\hline Bagus & $3 \%$ & 3 \\
\hline Sedang & $15 \%$ & 2 \\
\hline Cukup & $25 \%$ & 1 \\
\hline
\end{tabular}

untuk pengukuran hasil dari Packet Loss menggunakan persamaan dibawah ini [] .

$$
\text { PacketLoss }=\frac{\text { Paket data dikirim }- \text { Paket data diterima }}{\text { Paket data dikirim }} \times 100 \%
$$

3. Pengujian Delay

Pengujian ini dilakukan untuk mengetahui waktu yang dibutuhkan data untuk menempuh jarak dari asal ketujuan. [6].

Untuk indeks kualitas Delay dapat dilihat pada tabel 5 dibawah ini.

Tabel 5. Indeks kualitas Delay[ㅌ]

\begin{tabular}{llc}
\hline \multicolumn{1}{c}{$\begin{array}{c}\text { Kategori } \\
\text { Delay }\end{array}$} & \multicolumn{1}{c}{ Delay } & Indeks \\
\hline Sangat Bagus & $<150 \mathrm{~ms}$ & 4 \\
\hline Bagus & $150 \mathrm{~s} / \mathrm{d} 300 \mathrm{~ms}$ & 3 \\
\hline Sedang & $300 \mathrm{~s} / \mathrm{d} 450 \mathrm{~ms}$ & 2 \\
\hline Cukup & $>450 \mathrm{~ms}$ & 1
\end{tabular}

untuk pengukuran hasil dari Delay menggunakan persamaan dibawah ini .

$$
\text { Dellay }=\frac{\text { total delay }}{\text { total paket yang diterima }}
$$

4. Pengujian Jitter

Pengujian ini dilakukan untuk mengetahui variasi delay yang berhubungan erat dengan latency, yang menunjukkan banyaknya variasi delay pada transmisi data di jaringan.

Untuk indeks kualitas Delay dapat dilihat pada tabel 6 dibawah ini. 
Tabel 6. Indeks kualitas Jitter

\begin{tabular}{lcc}
\hline \multicolumn{1}{c}{$\begin{array}{c}\text { Kategori } \\
\text { Jitter }\end{array}$} & Jitter & Indeks \\
\hline Sangat Bagus & $0 \mathrm{~ms}$ & 4 \\
\hline Bagus & $0 \mathrm{~s} / \mathrm{d} 75 \mathrm{~ms}$ & 3 \\
\hline Sedang & $75 \mathrm{~s} / \mathrm{d} 125 \mathrm{~ms}$ & 2 \\
\hline Cukup & $125 \mathrm{~s} / \mathrm{d} 225 \mathrm{~ms}$ & 1
\end{tabular}

untuk pengukuran hasil dari Jitter menggunakan persamaan dibawah ini.

$$
\text { Jitter }=\frac{\text { Total variasi delay }}{\text { Total paket yang diterima }}
$$

5. Pengujian Keamanan

Pengujian keamanan dilakukan dengan menggunakan web amikom, selanjutnya dilakukan pemantauan jaringan mengenai input data yang dimasukkan oleh user pada web old.amikom.ac.id. Penguji menggunakan web amikom old dikarenakan web ini masih menggunakan http, hal ini menjadi parameter bagian keamanan data oleh kedua protokol melakukan enkripsi data yang terkirim oleh user pada web yang menggunakan http.

\section{Hasil dan Pembahasan}

Setelah dilakukan proses pengujian maka diperoleh hasil untuk seluruh parameter Quality of Service seperti pada diagram dibawah ini.

1. Hasil Pengujian Throughput

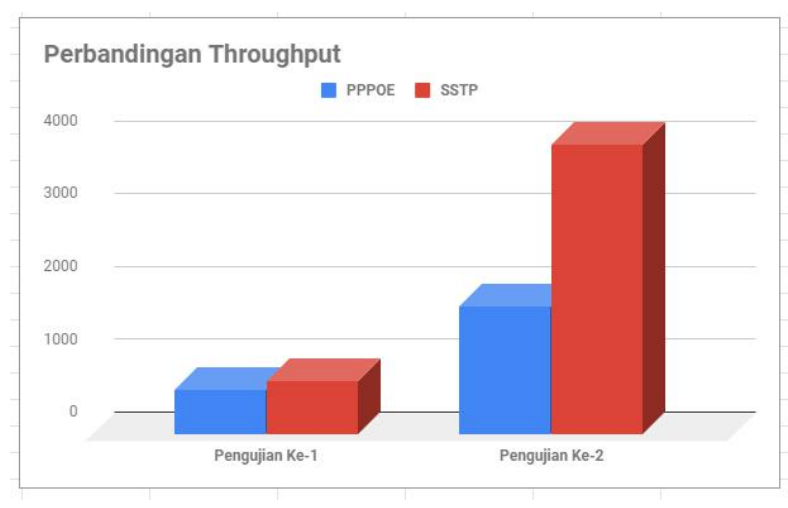

Gambar 3. Hasil Pengujian Throughput

Dari diagram gambar 3 diatas dapat dijelaskan bahwa pada pengujian pertama SSTP unggul dengan selisih $118 \mathrm{kbps}$, selanjutnya pada pengujian kedua SSTP masih unggul dengan nilai perbandingan yang begitu jauh yaitu 2266 kbps. Mengamatai dari hasil data diatas dapat disimpulkan pada variabel throughput SSTP lebih unggul dari PPPOE. 
2. Packet Pengujian Loss

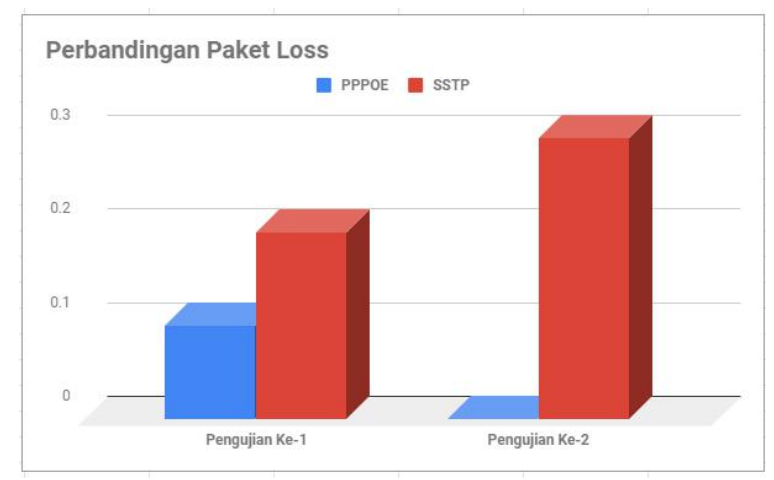

Gambar 4. Hasil Pengujian Packet Loss

Pada pengujian paket loss semakin kecil nilai yang di hasilkan maka semakin bagus kualitas nya, jadi dengan data diatas pada pengujian pertama lebih unggul PPPOE daripada SSTP, dengan selisih angka $0,001 \%$. Selanjutnya pada pengujian kedua PPPOE masih unggul dengan selisih nilai yang sangat jauh yaitu $0,003 \%$. Mengamatai dari hasil data diatas dapat disimpulkan pada variabel paket loss PPPOE lebih unggul dari SSTP.

3. Hasil Pengujian Delay

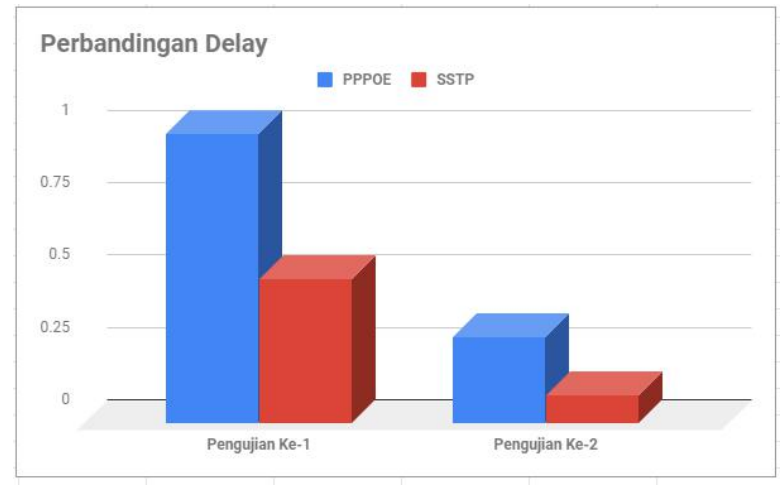

Gambar 5. Hasil Pengujian Delay

Pada pengujian delay semakin kecil nilai delay yang dihasilkan maka semakin bagus juga jaringan yang ada. Pada pengujian pertama data diagram diatas SSTP lebih unggul dengan nilai yang lebih kecil dari PPPOE. Selisih nilai PPPOE dengan SSTP yang dihasilkan pada pengujian pertama yaitu 0,045 ms. Selanjutnya pada pengujian kedua nilai delay semakin menurun daripada pengujian pertama, namun SSTP masih unggul dengan nilai yang lebih kecil dari PPPOE, selisih yang dihasilkan pada pengujian kedua ialah $0,002 \mathrm{~ms}$. 
4. Hasil Pengujian Jitter

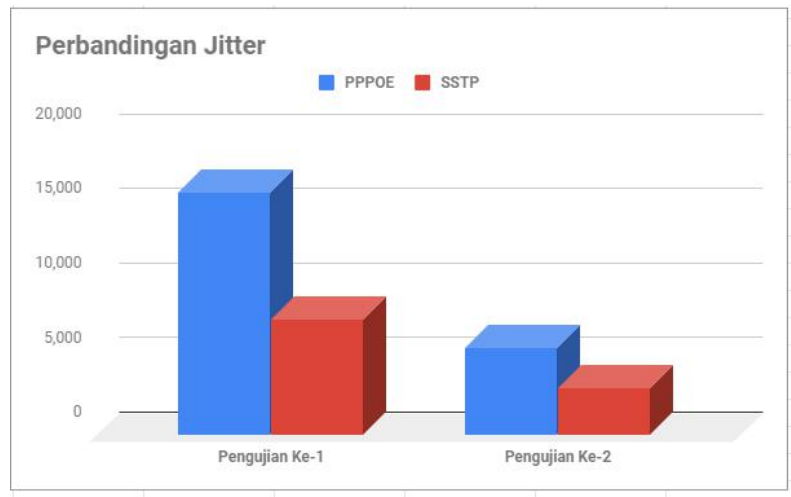

Gambar 6. Hasil Pengujian Jitter

Pada pengujian jitter semakin kecil nilai jitter yang dihasilkan maka semakin bagus juga jaringan yang ada. Pada data diagram diatas SSTP lebih unggul dengan nilai yang lebih kecil dari PPPOE. Selisih nilai PPPOE dengan SSTP yang dihasilkan pada pengujian pertama yaitu 8,506 ms. Selanjutnya pada pengujian kedua nilai jitter semakin menurun dari pada pengujian pertama, namun SSTP masih unggul dengan nilai yang lebih kecil dari PPPOE, selisih yang dihasilkan pada pengujian kedua ialah 2,771 ms.

5. Hasil Pengujian Keamanan

a. Filter packet data http yang lewat menggunakan aplikasi wireshark, pada protocol PPPOE.

Hasil dari tangkapan data http yang melalui protocol PPPOE dapat dilihat dari gambar 7 dibawah ini.

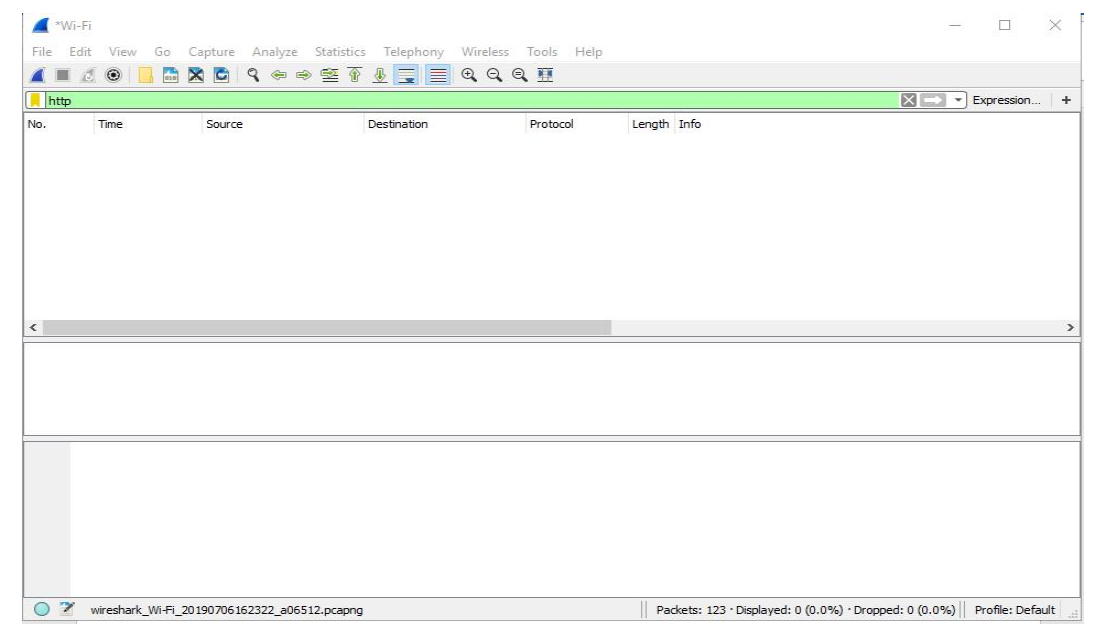

Gambar 7. Hasil Tangkapan data dari aplikasi Wireshark

Pada protocol PPPOE ditemukan bahwa packet data yang melintasi jaringan telah dilakukan enkripsi untuk memberikan keamanan lebih dalam jaringan. Terlihat pada gambar diatas, saat aplikasi wireshark melalukan filter data http, tidak ditemukan data yang melintas. Padahal user mengakses 
web http, tapi dengan adannya proses enkripsi data, maka data tidak bisa di filter atau dilihat oleh aplikasi wireshark.

b. Filter packet data http yang lewat menggunakan aplikasi wireshark, pada protocol SSTP.

Hasil dari tangkapan data http yang melalui protocol SSTP dapat dilihat dari gambar 8 dibawah ini.

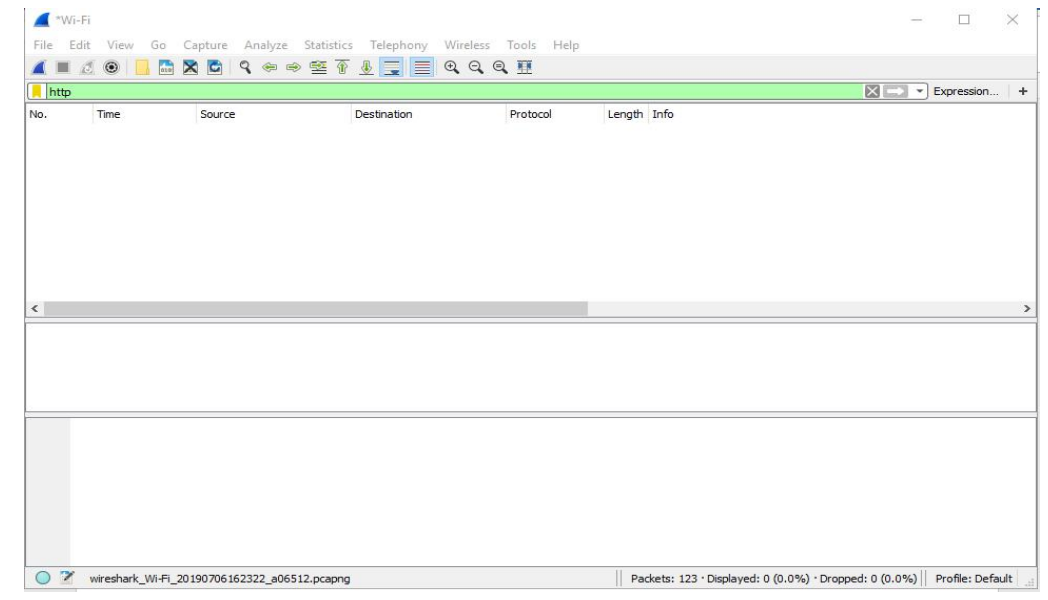

Gambar 8. Hasil tangkapan data pada aplikasi Wireshark

Pada protocol SSTP juga ditemukan hal yang sama, bahwa packet data yang melintasi jaringan telah dilakukan enkripsi untuk memberikan keamanan lebih dalam jaringan. Terlihat pada gambar diatas, saat aplikasi wireshark melalukan filter data http, tidak ditemukan data yang melintas. Padahal user mengakses web http, tapi dengan adannya proses enkripsi data, maka data tidak bisa di filter atau dilihat oleh aplikasi wireshark.

\section{Kesimpulan}

Diambil pada hasil pengujian dan setelah dibandingkan terdapat beberapa kesimpulan sebagai berikut.

a. Dalam aspek kualitas delay SSTP lebih unggul jika dibandingkan dengan PPPOE, nilai pengujian pertama SSTP $0.005 \mathrm{~ms}$ dan PPPOE 0.01, pada pengujian kedua nilai SSTP $0.001 \mathrm{~ms}$ dan PPPOE $0.003 \mathrm{~ms}$. Namun nilai kedua protokol ini dalam parameter tabel TIPHON memiliki kedudukan yang sama yaitu dalam kategori memiliki angka dibawah $<150 \mathrm{~ms}$ yang artinya dalam kategori sangat bagus.

b. Dalam aspek kualitas jitter SSTP lebih unggul jika dibandingkan dengan PPPOE, nilai pengujian pertama SSTP 7.739 ms dan PPPOE $16.245 \mathrm{~ms}$, pada pengujian kedua nilai SSTP $3.156 \mathrm{~ms}$ dan PPPOE $5.867 \mathrm{~ms}$. Namun nilai kedua protokol ini dalam parameter tabel TIPHON memiliki kedudukan yang sama yaitu dalam kategori memiliki angka dibawah $<75 \mathrm{~ms}$ yang artinya dalam kategori bagus.

c. Dalam aspek kualitas paket loss PPPOE lebih unggul jika dibandingkan dengan SSTP, nilai pengujian pertama SSTP $0002 \%$ dan PPPOE $0.001 \%$, pada pengujian kedua nilai SSTP $0.003 \%$ ms dan PPPOE $0 \%$. Namun nilai kedua protokol ini dalam parameter tabel TIPHON memiliki kedudukan yang sama yaitu dalam kategori memiliki angka $0 \%$ yang artinya dalam kategori sangat bagus.

d. Dalam aspek kualitas throughput SSTP lebih unggul jika dibandingkan dengan PPPOE, nilai pengujian pertama SSTP 734 kbps dan PPPOE 0616 kbps, pada pengujian kedua nilai SSTP 3984 kbps dan PPPOE 1758. Namun nilai kedua protokol ini dalam parameter tabel TIPHON memiliki kedudukan yang sama yaitu dalam kategori memiliki angka persentase $100 \%$ data dikirim yang artinya dalam kategori sangat bagus.

e. Pada pengujian terakahir mengenai keamanan data, kedua protocol telah mengenkripsi data dari http. Terbukti pada saat menulis http tidak dapat di capture oleh aplikasi wireshark. Dapat diambil kesimpulan pada pengujian ini, kedua protokol memiliki keamanan yang sama dalam hal enkripsi paket data http. 
f. Kedua protokol memiliki kelebihan dan kekurangan yang berbeda, dari analisis masalah yang ditemukan sebelum melakukan pengujian, dimana terlihat perbandingan kelebihan dan kekurangan setiap protokol. Apabila menggunakan jaringan protokol PPPOE terdapat kecepatan download lebih besar dari kecepatan upload. Sedangkan pada jaringan protokol SSTP kecepatan upload lebih besar daripada kecepatan download. Hal tersebut bisa menjadi pertimbangan apabila menggunakan kedua protokol ini.

\section{Daftar Rujukan}

[1] Rein R.P, Ridha M.N, Rendy M., 2015. Analisa Qos VPN PPPOE Pada Jaringan Backbone Wireless MPLS. e-Proceeding of Engineering: Vol.2, No.2 Agustus 2015, pp. 2563

[2] Sugiyatno, Prima D.A., 2018. Virtual Private Network (VPN) Secure Socket Tunneling Protocol (SSTP) Menggunakan Raspberry Pi. Information System For Educators and Professionals, 4 (2), pp. 155-166.

[3] Eri P., Amir H., Edhy S., 2016. Analisa quality of service kinerja poin to point protocol over ethernet (PPPOE) dan point to point tunneling protocol (PPPTP). Jurnal Jarkom, 4 (1), pp. 29-37.

[4] Kaseger A.F., Xaverius B. N., Arie S. M , 2017. Perancangan dan Implementasi VPN Server dengan menggunakan Protokol SSTP (Secure Socket Tunneling Protocol) Studi Kasus Kampus Universitas Sam Ratulangi. Skripsi, Universitas Sam Ratulangi.

[5] I Putu H., Raisul A, 2017. Pengamanan Layanan Private Cloud Storage Menggunakan HTTPS, IPTables dan SSTP. Seminar Nasional TIK dan Ilmu Sosial (SocioTech), STMIK Bumigora, 10 Oktober 2017, Indonsia.

[6] Tiphon, 1999, "Telecommunication And Internet Protocol Harmonization Over Network (TIPHON) General Aspects Of Quality Of Service (OoS)”. TR 101329 V2.1.1. 